International Journal of Engineering \& Technology, $7(4.15)(2018) 435-439$
International Journal of Engineering \& Technology
SPC
Website: www.sciencepubco.com/index.php/IJET
Research paper

\title{
The Implementation of Flipped Classroom using Screencast-O-Matic to Improve Students' Verbal Linguistic Intelligence
}

\author{
Cahyo Hasanudin ${ }^{1 *}$, Ayu Fitrianingsih ${ }^{2}$ \\ ${ }^{1}$ Indonesian Language and Literature Education, IKIP PGRI Bojonegoro \\ ${ }^{2}$ English Language Education, IKIP PGRI Bojonegoro \\ *Corresponding author E-mail: cahyo.hasanudin@ikippgribojonegoro.ac.id
}

\begin{abstract}
This research aims to 1) implement flipped classroom model using screencast-o-matic, 2) investigate the improvement of verbal linguistic intelligence through the implementation of flipped classroom model using screencast-o-matic for the students of IKIP PGRI Bojonegoro in academic year 2017-2018. This research is classroom action research (CAR) conducted at IKIP PGRI Bojonegoro, the subjects of the research are the first year students in second semester of academic year 2017-2018. The indicators of the research are measured using N-Gain test with the normalized Gain index interpretation category. Data sources in this research are 1) learning activities 2) informants, 3) documentary data. Data collection technique used documentation methods,observations, and verbal linguistic test of Thomas Armstrong by using Likert scale. The results of this research show that 1) the implementation of flipped classroom uses six stages, 2) the improvement of students' verbal linguistic intelligence can be seen from the actions in every cycle. In the preliminary research, the researcher had measured the students' learning styles, from 30 students who were the subject of research. There were 6 students who had visual learning style, 7 students had auditory learning style, and 17 students had kinesthetic learning style. In cycle I, FLIP model is implemented and students' verbal linguistic intelligence is 61,43 . In cycle II, students' verbal linguistic intelligence is 81,03 . The conclusion of this research are 1) the the implementation of flipped classroom model using Screencast-O-Matic uses FLIP model, 2) the improvement of students' verbal linguistic intelligence in IKIP PGRI Bojonegoro can be classified into average category.
\end{abstract}

Keywords: flipped classroom, screencast-o-matic apps, verbal linguistic intelligence, university students, learning style.

\section{Introduction}

Reading is one of language skills (reading, writing, speaking, and listening). Reading skill is active-receptive skill, so it can be developed separated from listening and speaking skills. However, in the community that has developed reading habit, reading skill is developed with listening and speaking skills. Tarigan[1] says that reading is a process carried out by readers to obtain information provided by the writer through his written language. According to Susanto [2] reading translates the symbol (letter) into sounds that is combined using words. Reading is also a process that is done and used by readers to obtain information provided by the writer through his written language[3]. Reading skill is taught in Indonesian language and literature department, IKIP PGRI Bojonegoro. Based on the curriculum, reading skill in this department has a code MKK 205 with 4 credit hours and is taught in the second semester.

In line with this course identity, the researcher finds problems related to the teaching of reading skill after interviewing the lecturer of reading skill in the even semester. Based on the results of interview, the researcher believes that students do not have the real concept of reading skill; some of them haven't applied the reading methods well. Besides, the results of interview with the first year students prove that they are bored with the lecturer's teaching method. Moreover, the teaching media is still traditional ones. This complicated problems must be given a solution, one of the solution proposed by the researcher is the implementation of flipped classroom using screencast-o-matic. The collaboration of this teaching method and media application is expected to make the students have verbal linguistic intelligence. According to Gardner in Armstrong[4], linguistic intelligence blew out in the early childhood until adult.

Flipped classroom method was first introduced by Bergmann and Aaron in 2007. Since then, many researchers have examined its impact on teaching. Generally, the flipped classroom method inverts traditional classroom teaching. This means that the students have to read or study at home, so the teacher does not need to explain the study materials in the classroom. Then, the students carry out assignments in the class. Basal [5] says that flipped classroom is teaching process in which learners have to study the theory by themselves then they are able to implement it. Furthermore, Herala, et al [6] said that flipped classroom is a method in which learners study the theory first freely outside the class and practice inside the class under the teacher's guidance.

Students in the class have to discuss about what they have read before at home or they only do the assignment given by the teacher. Then, they try to implement the knowledge by solving the problems and having group work discussion. The teacher's role in the class is not to give lecturing, because it wastes the time. His role is only as a facilitator and observer of the learning process. In line with Damayanti and Sutami [7] that flipped classroom gives usual classroom activities and homeworks then inverts it. The core of flipped classroom, according to Chandra and Yulius[8], 1) pro- 
vide more time in the class to assimilate the materials in form of exercise or another activities, and 2) accomodate the students' differences in motivation, mastering skill, and another knowledge. Based on Johnson[9] Flipped classroom method is a strategy that is given by the teacher by minimalizing the direct instruction and maximizing the students' interactions. This strategy utilizes technology that can provide online materials. It saves more time for doing classroom activities.

Adopting the experts' opinions above, it has been clear that flipped classroom needs technology. It can be in form of applications, videos, or networks. Flipped classroom creates students to get materials not only in the class but also out of the class they can access the material many times by using internet or playing videos as prepared by Khan Academy.

Concerned with the use of video in flipped classroom teaching, the researcher combines this teaching method with screencast-o-matic media application. This combination is profitable and able to improve the verbal linguistic intelligence in course of reading skill. Screencast-O-Matic Apps is a Java-based application media that is used to make screencasts in Windows, Mac, and Linux operating systems. Screencast-O-Matic Apps provides free software that enables the user to record all views and motions of their monitor, even the motion of the cursor and click instructions, add explanations or comments, and is easy to use. Priowirjanto et al.[10] said that Screencast-O-Matic Apps was a software that could be used by the users of Windows $15 \mathrm{Xp}$, Windows Vista, and Windows 7 operating systems. Screencast-O-Matic Apps can also be used to record webcam activities, so any tutorial may be recorded and shared on YouTube or a blog.

\section{Method}

According to the characteristics of the problems and its aim, this research is classroom action research (CAR). This research is the implementation of flipped classroom using screencast-o-matic to improve students' verbal linguistic intelligence in course of reading skill. It uses two cycles, in every cycle has been done through the stages of planning, doing, observing, and reflecting the action. This research is held in Indonesian language and literature department of IKIP PGRI Bojonegoro in academic year 2017-2018, and the subjects of the research are the first year students in second semester.

The indicator of the research is measured using N-Gain test with the formula

$$
\text { Normalized Gain }(g)=\frac{\text { Postest score }- \text { pretest score }}{\text { maximum score }- \text { pretest score }}
$$

Whereas the normalized Gain index interpretation category works as follow

Table 1. Normalized Gain Score

\begin{tabular}{|c|c|}
\hline Normalized Gain Score & Interpretation \\
\hline$-1.00<\mathrm{g}>0.00$ & Decrease \\
\hline $\mathrm{G}=0.00$ & stable \\
\hline $0.00<\mathrm{g}>0.30$ & low \\
\hline $0.30<\mathrm{g}>0.70$ & average \\
\hline $0.70<\mathrm{g}>1.00$ & high \\
\hline
\end{tabular}

Data and sources of data in this research can be seen in the following table.

Table 2. Data and Sources of Research Data

\begin{tabular}{|c|c|c|c|}
\hline Sources of data & & Taken data & instrumen \\
\hline $\begin{array}{l}\text { Learning activities of flipped classroom using } \\
\text { screencast-o-matic }\end{array}$ & & $\begin{array}{l}\text { Data of students' activities in the learning process } \\
\text { Data of lecturer's activities in the learning process }\end{array}$ & $\begin{array}{l}\text { Observation sheet } \\
\text { Observation sheet }\end{array}$ \\
\hline Informant & & $\begin{array}{l}\text { Data of students' background knowledge } \\
\text { Data of students' perceptions towards flipped classroom } \\
\text { teaching using screencast-o-matic } \\
\text { Students' verbal linguistic intelligence }\end{array}$ & $\begin{array}{l}\text { Interview sheet } \\
\text { Questionnaire } \\
\text { Questions about verbal linguistic } \\
\text { intelligence }\end{array}$ \\
\hline Dokumentary data & & $\begin{array}{l}\text { Teaching documents of flipped classroom using screencast-o- } \\
\text { matic } \\
\text { Notes about students' development }\end{array}$ & $\begin{array}{l}\text { Dokumentary sheet } \\
\text { Observation sheet }\end{array}$ \\
\hline
\end{tabular}

Techniques of collecting data in this research are three ways, i.e. documentation, observation, and test methods. Research instruments in this research are archives, observation sheets, and questions about verbal linguistic intelligence. Archives is about the achievement index of first semester as consideration in building heterogeneous groups. Observation sheets are used to collect the data of students activities in learning process to consider the reflection in the next cycle. The questions about verbal linguistic intelligence are used to gain the data of students' verbal linguistic intelligence. They are asked to answer the questions related to reading skill.

In line with the orientations made before, the researcher moves it to a format of research instruments that will be given to the respondent as data of verbal linguistic test. The number of total statements in the instrument are 20 questions with total score 1-5 (using Likert scale). Sugiyono [11] says that Likert scale is used to measure attitude, opinion, someone's perception about social phenomena.

Therefore, Likert scale is the most suitable in measuring respondent's intelligence. The assessment format of verbal linguistic test is in form of tables. The following is the assessment format.

\section{$K L=$ the sum of score}

Notes:
1. The Highest Score Likert scale)

2. The Lowest Score $\quad=20 \quad(20$ questions $\times 1$ the lowest Likert scale)

The analysis has been done in a descriptive qualitative manner with interactive technique based on the results of observation towards the process and result of learning, the steps are 1) reducing, 2)interpreting, 3) inferencing, and 4) having follow up. The conclusion making is based on analysis of observation results to be interpreted in form of statements.

\section{Result and Discussion}

\subsection{The implementation of flipped classroom using screencast-o-matic in a course of reading skill}

Based on the observation results toward flipped classroom teaching, the lecturer implements the steps of instructions in line with Bergmann and Sams[12], i.e. 1) what to do on the first day, 2) inform about the flipped classroom model, 3) teach students how to watch and interact with the videos, 4) instruct students to ask interesting questions, 5) encourage students to help each other, 6) build an appropriate assessment system. 
- On the first day of flipped classroom teaching, the researcher interviews the lecturer of reading skill.

- The researcher informs the flipped classroom model to the lecturer of reading skill.

- The researcher teaches students how to access the video by downloading the file in https://www.youtube.com/watch?v=vUhq8tceSho\&t=11 s, and
https://www.youtube.com/watch?v=vUhq8tceSho\&t=11 $\mathrm{s}$,

- The researcher instructs the students to ask questions about the material downloaded.

- The researcher leads students to remember, understand, and be able to ask questions. In this step, the lecturer gives opportunities for all of students to interact each other by asking them to answer and give their opinion related to the questions. The lecturer, in this step, always implements "FLIP" model.

\begin{tabular}{|c|c|c|}
\hline Letters & Acronyms & Mable 3. FLIP model \\
\hline F & $\begin{array}{c}\text { Flexible } \\
\text { Environment }\end{array}$ & $\begin{array}{c}\text { Students can study the materials (videos) anytime and anywhere. This means that the students do not need to be sat } \\
\text { at their desk listening to the teacher's explanation directly. }\end{array}$ \\
\hline L & Learning Culture & This model is a form of student-centred learning. So, the students will be more active in knowledge construction. \\
\hline I & $\begin{array}{c}\text { Intentional } \\
\text { Content }\end{array}$ & $\begin{array}{c}\text { The teacher implements the model so that students are more engaged in the learning process and their cognitive } \\
\text { understanding is developed. }\end{array}$ \\
\hline P & $\begin{array}{c}\text { Professional } \\
\text { Teacher }\end{array}$ & $\begin{array}{c}\text { The teacher has the role of observing the students, evaluating their studies and giving feedback. So, he must be } \\
\text { professional. }\end{array}$ \\
\hline
\end{tabular}

- Build an assessment system

The findings are in line with Bergmann and Sams[12], who say that various models of assessment are available to the educator. In this case, the teacher evaluates the students individually and in groups. He assesses them on an A-D grade scale. The students who get $\mathrm{C}$ and $\mathrm{D}$ grades can take remediation provided by the teacher. This has been established to support students in mastering reading skills in the Indonesian language

The implementation of flipped classroom using screencast-o-matic in reading skill at Indonesian language and literature department is the first collaboration implemented in this department. It increases the list of recent teaching model and media implementation. It is able to extend the innovation of the learning process in this department.

Based on the observations, the researcher has analysed that 27 students have downloaded the videos from YouTube. In fact, the total number of students is 30 persons. It can therefore be concluded that 90 percent of the students are really motivated to study the videos as the learning materials. Meanwhile, the lecturer acts as the facilitator in the classroom. Students are eager to discuss and present their arguments. Based on the students' opinions given in the interview process, they are truly motivated and able to enjoy their leisure time greatly. They are able to give fast respons to the questions given and learn how to appreciate another's opinions. Finally, this implementation creates students to have comprehensive knowledge about reading skill materials.

\subsection{The improvement of students' verbal linguistic in- telligence at IKIP PGRI Bojonegoro in academic year 2017-2018}

In accordance with the aims of CAR, i.e. develop and improve the teaching and learning. This research begins with the stages of 1) preliminary research; it observes the planning of learning, lecturer's activities, students' activities and outcomes in the learning process of reading skill, 2) first cycle, and 3) second cycle.

a) The initial condition of students' verbal linguistic intelligence

Before doing action research, the first step is investigating the initial condition of students. However, the researcher measures the students' learning styles first. The result of it can be seen in the table below.

Table 4. students' learning style
\begin{tabular}{|l|l|l|}
\hline \multicolumn{1}{|c|}{ The number of students } & percentage \\
\hline Visual & 6 & $20 \%$ \\
\hline Auditory & 7 & $23,3 \%$ \\
\hline Kinesthetic & 17 & $56,67 \%$ \\
\hline
\end{tabular}

As a result, the researcher concludes that not all of the students have good language skill, most of them adopt kinesthetic learning style. It is validated by interviewing the kinesthetic students, the results show that they are graduated from science department in their senior high schools.

Based on results of observation and interview, the researcher and the lecturer have a deep discussion to renew the learning process. They decide to implement flipped classroom model using screencast-o-matic media apps. It is expected to improve the students' verbal linguistic intelligence.

\section{b) Doing action in cycle I}

Cycle I starts from planning, doing, observing, analysing, and reflecting.

\section{1) Planning action}

The researcher and the lecturer discuss the plan in the process of classroom action research. At this time, they act as collaborator. Things to be discussed are: 1) the researcher explains his perception about this research, 2) he proposes the implementation of flipped classroom model, 3) they arrange proper lesson plan for cycle I, 4) they make assessment sheets of test and non-test, 5) they decide the schedule for doing action.

\section{2) Doing action}

The initial activity is greeting the students. The lecturer also examines the students' attendance. Then, he asks about the video that had been uploaded in youtube. It is done to know whether or not the students have studied the material. This is based on flipped classroom method.

In the previous meeting the lecturer had instructed the students to download the video in youtube. After downloading it, they were able to study the materials at home or anywhere many times until they got understood $(\mathrm{F}=$ Flexible Environment $)$.

In the classroom, the lecturer examines the students' understanding by instructing them to work in groups. They are able to ask each other and conclude together. In this step, the students act as centered learning, while the lecturer acts as observer and facilitator $(\mathrm{L}=$ Learning Culture).

The lecturer gives opportunities to interact each other, it is expected to make students have better cognitive knowledge. The interaction can be seen when one of the students gives her opinion, the others comment on it. It is clear that the lecturer is not only teaching students but also guiding them to solve the problems ( $\mathrm{I}=$ Intentional Content).

At the upper stage, lecturer's role is to observe the classroom learning process carefully. He must be able to give feedback, conclusion, and the best solution about the problems. At this time, the lecturer is claimed to be professional in giving assessment $(\mathrm{P}=$ Professional Teacher).

\section{3) Observing}


In this stage, the researcher observes the learning process of reading skill in which flipped classroom method is implemented and the questionnaire of verbal linguistic intelligence is used to examine the students' verbal linguistic intelligence in reading skill.

Based on the result of questionnaire in cycle I, it can be stated that there is an improvement of students' verbal linguistic intelligence compared to the initial condition. Though, not all the indicators are achieved.

4) Analysing and Reflecting

The data got from the observations are collected to be analysed. The data is analysed using categories in Likert scale.

Table 5. The result of students' verbal linguistic test based on Likert scale in cycle I

\begin{tabular}{|c|c|c|c|c|c|c|c|}
\hline \multirow{2}{*}{ Aspects } & \multirow{2}{*}{ Items of Questionnaire } & \multirow{2}{*}{$\begin{array}{l}\text { Items of state- } \\
\text { ment }\end{array}$} & \multicolumn{5}{|c|}{ Absolute Frequency } \\
\hline & & & 5 & 4 & 3 & 2 & 1 \\
\hline \multirow[t]{2}{*}{1} & \multirow{2}{*}{ Books are very important for me } & 1 & 7 & 11 & 2 & 2 & 6 \\
\hline & & 2 & 8 & 4 & 8 & 3 & 5 \\
\hline \multirow[t]{2}{*}{2} & \multirow[t]{2}{*}{ I can hear words in my head before I read, speak, or write them down. } & 1 & 10 & 6 & 4 & 5 & 3 \\
\hline & & 2 & 10 & 8 & 2 & 5 & 3 \\
\hline \multirow[t]{2}{*}{3} & \multirow{2}{*}{$\begin{array}{l}\text { I get more out of listening to the radio or a spoken-word recording than I do from television or } \\
\text { films. }\end{array}$} & 1 & 5 & 8 & 6 & 5 & 4 \\
\hline & & 2 & 6 & 7 & 7 & 3 & 5 \\
\hline \multirow[t]{2}{*}{4} & \multirow[t]{2}{*}{ I enjoy word games like Scrabble, Anagrams, or Password. } & 1 & 6 & 4 & 4 & 10 & 5 \\
\hline & & 2 & 7 & 2 & 8 & 7 & 5 \\
\hline \multirow[t]{2}{*}{5} & \multirow[t]{2}{*}{ I enjoy entertaining myself or others with tongue twisters, nonsense rhymes, or puns. } & 1 & 1 & 9 & 5 & 8 & 5 \\
\hline & & 2 & 3 & 10 & 4 & 8 & 5 \\
\hline \multirow[t]{2}{*}{6} & \multirow{2}{*}{$\begin{array}{l}\text { Other people sometimes have to stop and ask me to explain the meaning of the words I use in } \\
\text { my writing and speaking. }\end{array}$} & 1 & 9 & 4 & 6 & 5 & 4 \\
\hline & & 2 & 4 & 10 & 7 & 4 & 3 \\
\hline \multirow[t]{2}{*}{7} & \multirow[t]{2}{*}{ English, social studies, and history were easier for me in school than math and science } & 1 & 7 & 4 & 7 & 5 & 5 \\
\hline & & 2 & 6 & 4 & 5 & 7 & 6 \\
\hline \multirow[t]{2}{*}{8} & \multirow{2}{*}{$\begin{array}{l}\text { Learning to speak or read another language (e.g., French, Spanish, German) has been relatively } \\
\text { easy for me. }\end{array}$} & 1 & 7 & 7 & 6 & 4 & 4 \\
\hline & & 2 & 6 & 5 & 8 & 7 & 3 \\
\hline \multirow[t]{2}{*}{9} & \multirow[t]{2}{*}{ My conversation includes frequent references to things that I've read or heard } & 1 & 6 & 3 & 6 & 8 & 6 \\
\hline & & 2 & 6 & 4 & 9 & 4 & 5 \\
\hline \multirow[t]{2}{*}{10} & \multirow{2}{*}{$\begin{array}{l}\text { I've written something recently that I was particularly proud of or that earned me recognition } \\
\text { from others. }\end{array}$} & 1 & 5 & 2 & 7 & 8 & 5 \\
\hline & & 2 & 5 & 10 & 4 & 3 & 5 \\
\hline
\end{tabular}

The purpose of reflection is to know the strengths and weaknesses of the cycle, the problems and solutions for the next cycle. According to the observation in cycle I, there is no great changes. In observing the learning process, it has been known that students haven't had great verbal linguistic intelligence. The lecturer tries to record the materials well, but there are still some students who haven't reached the good achievement.

Besides, in cycle I there are some strength, 1) students are more motivated to study by playing the video at home many times while doing their another activities, 2) lecturer compiled the learning materials very well, 3 ) researcher records the lecturer's material carefully.

The results of learning process in cycle I show that there is a little change. It is known by examining the students' verbal linguistic intelligence that is increased.

c) Doing action in cycle II

Actuallly, the action in cycle II is the same as in cycle I. The actions that has been done in cycle II are :

1) Planning action

Planning stage in cycle II is based on the results of analysis and reflection in cycle I. In this cycle, the researcher and lecturer discuss to find the best solutions of the problems in the previous cycle. They arrange the instruments in form of lesson plans and the guidances of observation.

2) Doing action

The initial activity is greeting the students. The lecturer also examines the students' attendance. Then, he asks about the video that had been uploaded in youtube. It is done to ascertain whether or not the students have studied the material. This is based on flipped classroom method.
In the previous meeting the lecturer had instructed the students to download the video in youtube. After downloading it, they were able to study the materials at home or anywhere many times until they got understood ( $\mathrm{F}=$ Flexible Environment).

In the classroom, the lecturer examines the students' understanding by instructing them to work in groups. They are able to ask each other and conclude together. In this step, the students act as centered learning, while the lecturer acts as observer and facilitator $(\mathrm{L}=$ Learning Culture).

The lecturer gives opportunities to interact each other, it is expected to make students have better cognitive knowledge. The interaction can be seen when one of the students gives her opinion, the others comment on it. It is clear that the lecturer is not only teaching students but also guiding them to solve the problems (I = Intentional Content).

At the upper stage, lecturer's role is to observe the classroom learning process carefully. He must be able to give feedback, conclusion, and the best solution about the problems. At this time, the lecturer is claimed to be professional in giving assessment $(\mathrm{P}=$ Professional Teacher).

3) Observing

In this stage, the researcher observes the learning process of reading skill in which flipped classroom method is implemented and the questionnaire of verbal linguistic intelligence is used to examine the students' verbal linguistic intelligence in reading skill.

Based on the result of questionnaire in cycle II, it can be stated that there is an improvement of students' verbal linguistic intelligence compared to cycle I. Though, not all the indicators are achieved.

4) Analysing and Reflecting Analisis dan refleksi

The data got from the observations are collected to be analysed.

The data is analysed using categories in Likert scale.

Table 6. Result of students' verbal linguistic testBased on the Likert scale in cycle I

\begin{tabular}{|c|c|c|c|c|c|c|c|}
\hline \multirow{2}{*}{ Aspects } & \multirow{2}{*}{ Items of Questionnaire } & \multirow{2}{*}{$\begin{array}{l}\text { Items of state- } \\
\text { ment }\end{array}$} & \multicolumn{5}{|c|}{ Absolute Frequency } \\
\hline & & & 5 & 4 & 3 & 2 & 1 \\
\hline \multirow[t]{2}{*}{1} & \multirow{2}{*}{ Books are very important for me } & 1 & 11 & 10 & 8 & 0 & 0 \\
\hline & & 2 & 15 & 11 & 4 & 0 & 0 \\
\hline \multirow[t]{2}{*}{2} & \multirow[t]{2}{*}{ I can hear words in my head before I read, speak, or write them down. } & 1 & 12 & 9 & 7 & 0 & 0 \\
\hline & & 2 & 9 & 11 & 9 & 0 & 0 \\
\hline \multirow[t]{2}{*}{3} & \multirow{2}{*}{$\begin{array}{l}\text { I get more out of listening to the radio or a spoken-word recording than I do from television or } \\
\text { films. }\end{array}$} & 1 & 11 & 12 & 7 & 0 & 0 \\
\hline & & 2 & 5 & 13 & 11 & 0 & 0 \\
\hline
\end{tabular}




\begin{tabular}{|c|c|c|c|c|c|c|c|}
\hline \multirow{2}{*}{ Aspects } & \multirow{2}{*}{ Items of Questionnaire } & \multirow{2}{*}{$\begin{array}{l}\text { Items of state- } \\
\text { ment }\end{array}$} & \multicolumn{5}{|c|}{ Absolute Frequency } \\
\hline & & & 5 & 4 & 3 & 2 & 1 \\
\hline \multirow[t]{2}{*}{4} & \multirow[t]{2}{*}{ I enjoy word games like Scrabble, Anagrams, or Password. } & 1 & 5 & 11 & 13 & 0 & 0 \\
\hline & & 2 & 12 & 11 & 7 & 0 & 0 \\
\hline 5 & I enjoy entertaining myself or others with tongue twisters, nonsense rhymes, or puns. & 2 & 11 & 11 & 8 & 0 & 0 \\
\hline \multirow[t]{2}{*}{6} & \multirow{2}{*}{$\begin{array}{l}\text { Other people sometimes have to stop and ask me to explain the meaning of the words I use in } \\
\text { my writing and speaking. }\end{array}$} & 1 & 9 & 10 & 10 & 0 & 0 \\
\hline & & 2 & 8 & 12 & 8 & 0 & 0 \\
\hline \multirow[t]{2}{*}{7} & \multirow[t]{2}{*}{ English, social studies, and history were easier for me in school than math and science } & 1 & 12 & 11 & 6 & 0 & 0 \\
\hline & & 2 & 10 & 10 & 10 & 0 & 0 \\
\hline \multirow[t]{2}{*}{8} & \multirow{2}{*}{$\begin{array}{l}\text { Learning to speak or read another language (e.g., French, Spanish, German) has been relatively } \\
\text { easy for me. }\end{array}$} & 1 & 12 & 8 & 10 & 0 & 0 \\
\hline & & 2 & 10 & 12 & 8 & 0 & 0 \\
\hline \multirow[t]{2}{*}{9} & \multirow[t]{2}{*}{ My conversation includes frequent references to things that I've read or heard } & 1 & 11 & 11 & 8 & 0 & 0 \\
\hline & & 2 & 13 & 4 & 12 & 0 & 0 \\
\hline \multirow[t]{2}{*}{10} & \multirow{2}{*}{$\begin{array}{l}\text { I've written something recently that I was particularly proud of or that earned me recognition } \\
\text { from others. }\end{array}$} & 1 & 8 & 12 & 9 & 0 & 0 \\
\hline & & 2 & 12 & 10 & 6 & 0 & 0 \\
\hline
\end{tabular}

The purpose of reflection is to know the strengths and weaknesses of the cycle, the problems and solutions for the next cycle. According to the observation in cycle II, there is great changes.

Results of actions in cycle I and cycle II are measured using NGain test with the formula:

Normalized Gain $(g)=\frac{\text { Postest score }- \text { pretest score }}{\text { maximum score }- \text { pretest score }}$

Normalized Gain $(g)=\frac{81,03-61,43}{100-61,43}$

Normalized Gain $(g)=0,508$

The result of both cycles is interpreted using the interpretation of normalized Gain index (g). The observations show that students' verbal linguistic intelligence in course of reading skill by implementing flipped classroom is good (average). The recording materials are well accepted, so the students' verbal linguistic intelligence is more improved in every cycle.

The results of this research about the implementation of flipped classroom are supported by Nouri[13]. Nouri observes the students with positive attitudes toward flipped classroom have more positive attitudes toward the videos, increasing motivation, and more effective learning improvement. The students agree that flipped classroom make them more active. They appreciate the learning through the videos that are easy to be accessed. Another research done by Roehl and Linga [14] to introduce some new learning models that are transferred from teacher and students thinking. Teacher has to conduct research with alternative models in the class. As an instructor, it is important to create effective learning. Flipped classroom model that used technology aid, makes students are able to think more creatively. Whether the use of screencast-o-matic media apps is supported by the research done by Suryanto [15], [16]that students taught by using screencast-o-matic have better achievement, so this media is really recommended for all instructors.

In accordance with the previous researchs and its results, it can be said that flipped classroom and screencast-o-matic can be implemented together. It creates innovative learning and can be used to motivate the students in course of reading skill.

\section{Conclusion}

Implementing the flipped classroom using screencast-o-matic in course of reading skill begins with 1) asking the materials taught by the lecturer, then it is compiled and made using screencast-omatic media apps, 2) informing the flipped classroom model to the lecturer and giving the stages of it, 3) uploading the file to the browser (youtube) dan instructing the students to download it, 4) asking the students to make list of questions when the learning begins, 5) implementing flipped classroom model with FLIP Principles ( $\mathrm{F}$ : flexible environment, $\mathrm{L}$ : learning culture , I : intentional content, P: professional teacher), 6) lecturer builds appropriate assessment system.
The improvement of students' verbal linguistic intelligence at IKIP PGRI Bojonegoro in academic year 2017-2018 can be seen from the actions done in every cycle. In the preliminary study, the researcher had measured the students learning styles, from 30 students who were the subjects of research, there were 6 students had a visual learning style, 7 students had auditory learning style, and 17 students had kinesthetic learning style. Then in cycle I, by implementing FLIP approach, it is found that students' verbal linguistic intelligence is 61,43 and in cycle II, students' verbal linguistic intelligence is 81,03 . Based on the interpretation of normalized Gain index, it is concluded that the students of IKIP PGRI Bojonegoro have average verbal linguistic intelligence.

\section{Acknowledgement}

This study is funded by the Indonesian Ministry of Research, Technology, and Higher Education through Penelitian Dosen Pemula (PDP) research grant.

\section{References}

[1] H. G. Tarigan, Membaca sebagai suatu keterampilan berbahasa. Angkasa, 1987.

[2] A. Susanto, Perkembangan anak usia dini: Pengantar dari berbagai aspeknya. Kencana, 2011.

[3] S. Somadayo, "Strategi dan teknik pembelajaran membaca." Yogyakarta: Graha Ilmu, 2011.

[4] T. Armstrong, Multiple intelligences in the classroom. Ascd, 2009.

[5] A. Basal, "The implementation of a flipped classroom in foreign language teaching.," Turkish Online J. Distance Educ., vol. 16, no. 4, pp. 28-37, 2015.

[6] A. Herala, E. Vanhala, A. Knutas, and J. Ikonen, "Teaching programming with flipped classroom method: a study from two programming courses," in Proceedings of the 15th Koli Calling Conference on Computing Education Research, 2015, pp. 165-166.

[7] H. N. Damayanti and S. Sutama, "Efektivitas Flipped Classroom Terhadap Sikap Dan Ketrampilan Belajar Matematika Di Smk," Manaj. Pendidik., vol. 11, no. 1, pp. 2-7, 2016.

[8] F. H. Chandra and Y. W. Nugroho, "PERAN TEKNOLOGI VIDEO DALAM FLIPPED CLASSROOM."

[9] G. B. Johnson, "Student perceptions of the flipped classroom." University of British Columbia, 2013.

[10] G. Priowijanto, "Materi Simulasi Digital," Jakarta: Seamolec, 2013

[11] D. Sugiyono, "Prof. 2006," Metod. Penelit. Adm., 2006.

[12] J. Bergmann and A. Sams, Flip your classroom: Reach every student in every class every day. International society for technology in education, 2012.

[13] J. Nouri, "The flipped classroom: for active, effective and increased learning-especially for low achievers," Int. J. Educ. Technol. High. Educ., vol. 13, no. 1, p. 33, 2016.

[14] A. Roehl, S. Reddy-Linga, J. Kucko, and L. Prestwood, "The Importance of Teaching Cultural Awareness in Design Education: Evidence from Interior Design," Glob. J. Human-Social Sci. Res., 2013.

[15] H. Suryanto, "PENGEMBANGAN MULTIMEDIA E-LEARNING BERBASIS SCREENCAST-O-MATIC PADA PEMBELAJARAN MATEMATIKA UNTUK SISWA SEKOLAH MENENGAH PERTAMA KELAS VII," Devosi J. Teknol. Pembelajaran, vol. 5, no. 1 , pp. 11-21, 2015.

[16] H. Suryanto, "Pengembangan Multimedia E-Learning Berbasis Screencast-O-Matic Dalam Pembelajaran Matematika," J. STKIP PGRI Lamongan, vol. 1, no. 1, p. 6, 2017. 